\title{
PERBEDAAN HASIL RIAS WAJAH KARAKTER TUA DENGAN MENGGUNAKAN KOSMETIK BODY PAINTING dan PENSIL ALIS
}

\author{
Cindy Melynandra \\ Program Studi Pendidikan Tata Rias dan Kecantikan, Fakultas Pariwisata dan Perhotelan, Universitas Negeri Padang \\ email : cindy.melyn@gmail.com

\section{Murni Astuti} \\ Program Studi Pendidikan Tata Rias dan Kecantikan, Fakultas Pariwisata dan Perhotelan, Universitas Negeri Padang \\ email : murni.astuti937@gmail.com
}

\begin{abstract}
This study is on the makeup of old female characters performed by female students, lack of female understanding of wrinkle making techniques and proper selection of cosmetics in makeup of old female characters, this study aims to analyze the makeup of old female characters using body painting cosmetics and eyebrow pencil, and to find out the differences in the makeup of old female characters between the use of cosmetic body painting and eyebrow pencil. This type of research is a quasi experiment with a non equivalent control group design. The sampling technique is done by purposive sampling technique. The results of the analysis showed that in the experimental group 1 the use of cosmetic body painting (X1) with an average value of 3.5778 with a very good category. Furthermore, in the experimental group 2 using eyebrow pencil (X2) with an average value of 2.2444 with an unfavorable category.
\end{abstract}

\section{Keywords : Body Painting, Eyebrow Pencil, Old Character Face Makeup}

\section{PENDAHULUAN}

Pada saat sekarang ini merias wajah bukan suatu hal yang baru, dan seiring dengan perkembangan teknologi serta kemajuan kosmetik. konsep merias wajah telah mengalami perubahan yang cukup pesat dimana merias wajah tidak selalu untuk merubah wajah menjadi cantik. tetapi juga dimanfaatkan untuk merubah karakter wajah atau yang dikenal dengan istilah rias wajah karakter baik itu menjadi tua, menjadi karakter binatang, laki-laki menjadi perempuan ataupun perempuan menjadi laki-laki.

Tata rias wajah karakter adalah seni menggunakan bahan-bahan kosmetika untuk mewujudkan peran atau karakter dengan memperhatikan lighting dan jarak pandang penonton. Rias wajah karakter merupakan tata rias untuk meniru karakter-karakter lain yang kemungkinan menghendaki perubahan-perubahan seperti penambahan kumis, jenggot, bentuk mata, alis dan hidung atau keperluan lainnya sesuai degan karakter yang dinginkan (Kusantati, 2008:499).
Character make up atau tata rias karakter adalah suatu tata rias yang diterapkan untuk mengubah penampilan seseorang dalam hal umur, sifat, wajah, suku, dan bangsa sehingga sesuai dengan tokoh yang diperankannya (Paningkiran, 2013: 11). Direktorat Pembinaan Kursus dan Pelatihan (2016:6) juga menjelaskan tentang rias karakter sebagai berikut:

Rias wajah karakter dimaksudkan untuk membantu aktor menggambarkan suatu peran dengan membuat wajah atau muka pemain menyerupai muka peranan watak yang akan dimainkan. Oleh karena itu Rias karakter yang merupakan bagian dari rias wajah film harus lebih halus daripada rias wajah foto, karena untuk rias wajah film, kamera bergerak sehingga kesalahan sekecil apapun akan terlihat dan karenanya diperlukan ketelitian yang ekstra dalam merias wajah karakter pada foto/film.

Berdasarkan uraian di atas dapat disimpulkan bahwa tata rias karakter adalah tata rias yang diterapkan untuk mengubah penampilan seseorang dan menggambarkan suatu peran yang akan dimainkan. Dengan demikian rias karakter memiliki bermacam-macam bentuk, sesuai dengan peran masing-masing pemainnya. 
Menurut Thowok (2012:14) macam-macam rias wajah karakter, yaitu : (1) Rias wajah karakter : Keras, Pesimis, Nenek, Kakek (2) Rias wajah karakter horor, (3) Rias karakter dewasa pria (4) Rias karakter cacat/luka (5) Rias karakter lucu/badut (6) Rias karakter binatang (7) Rias karakter nenek sihir. Salah satu riasan yang cukup sulit untuk dikerjakan yaitu rias karakter tua.

Depdiknas (2001:5) menjelaskan rias wajah karakter tua adalah rias wajah sebagaimana model kelihatan tua dari usia yang sebenarnya. Aprilya (2014:108) juga menambahkan penciptaan rias wajah karakter perempuan tua lebih sulit dikerjakan dibandingkan dengan rias wajah karakter pria tua. Hal tersebut dikarenakan sebelum melakukan tata rias wajah karakter perempuan tua perlu untuk diketahui watak, usia, latar belakang kehidupan dan tipe wanita yang akan dituangkan dalam bentuk tata rias wajah karakter perempuan tua.

Menurut Hakim dkk, dalam Pancawardani (2013:2) penciptaan tata rias wajah karakter perempuan tua tidak lepas dari kosmetik yang digunakan dan kosmetik body painting dan foundation merupakan kosmetik dekoratif yang dapat digunakan untuk tata rias wajah karakter perempuan tua. Paningkiran (2013:52-59) juga menambahkan kosmetik yang biasa digunakan untuk tata rias wajah karakter perempuan tua dua dimensi biasanya terdiri atas eye shadow, krim body painting, foundation, dan pensil alis. Rias wajah karakter dua dimensi mengandalkan kekuatan pengecatan (painting) dari gelap terangnya warna (blending) serta memperhatikan anatomi wajah dari pemain dalam membuat efek keriput seperti kerutan pada dahi, pembenaman kelopak mata, pembenaman kantung mata, bayangan pada tulang pipi, gerakan pada pelipis, kerutan pada garis senyum, sudut bibir yang turun, kerutan di dagu, dan keriput pada leher. Semua hal tersebut harus diperhatikan dalam pembuatan kerutan, karena salah-salah dalam teknik pembuatan kerutan akan terlihat janggal sehingga dapat merusak penampilan pemain, dan untuk membuat kerutan lebih alami penata rias dapat menggunakan pensil alis maupun body painting.

Menurut Thowok (2012:31) pensil alis digunakan untuk mempertegas, membuat kerutan pada setiap kerutan pada rias wajah karakter perempuan tua. Sementara menurut Eko Santosa, dkk (2008:281) dalam pementasan teater, pensil alis juga dimanfaatkan untuk membuat garis-garis pembentuk pada wajah seperti membuat garis kerutan pada wajah. Sementara body painting adalah bahan yang bersifat opak (menutup) berbentuk krim dan stik. Bahan ini biasa digunakan untuk tata rias fantasi dan rias wajah karakter. Kosmetik body painting berfungsi pula untuk melukis badan, seperti membuat tato, kerutan pada wajah atau memberi warna pada bagian badan tertentu yang dikehendaki. Dapat dikatakan bahwa dalam pembentukan kerutan pada rias wajah karakter perempuan tua memperoleh hasil yang maksimal dibutuhkan kosmetik body painting dan pensil alis. Kosmetik Body painting dan pensil alis memiliki fungsi untuk membentuk garis kerutan pada rias wajah karakter perempuan tua. pembuatan kerutan juga harus disesuai dengan anatomi, usia serta karakter tokoh yang dimainkan, dan karenanya dalam membuat kerutan perempuan tua dibutuhkan teknik serta kosmetik yang tepat.

Dapat disimpulkan bahwa kosmetik body painting yang berbentuk krim dan pensil alis dapat digunakan dalam membantu dan menunjang membentuk kerut-kerutan pada saat rias wajah karakter perempuan tua.

Berdasarkan penelitian yang dilakukan oleh Aprilya (2014:110) mengungkapkan bahwa aspek kehalusan riasan pada karakter perempuan tua dengan menggunakan kosmetik body painting lebih halus dibandingkan dengan menggunakan foundation. Dari aspek ketajaman warna, hasil tata rias wajah karakter tua menggunakan kosmetik body painting lebih tajam dari pada foundation dilihat dari garis kerutan dan efek cekung yang diciptakan. Sementara dari aspek ketepatan garis kerutan, kosmetik body painting lebih tepat dibandingkan foundation. Secara keseluruhan, tata rias wajah karakter perempuan tua dengan menggunakan kosmetik body painting lebih baik dari pada yang menggunakan foundation.

Berdasarkan observasi yang penulis lakukan pada mahasiswi Tata Rias dan Kecantikan Universitas Negeri Padang Angkatan 2014 ditemukan bahwa temukan mahasiswi kurang memahami kosmetik yang tepat untuk merias karakter tua terlebih pada tokoh perempuan tua, dimana pembuatan kerutan terlihat kurang alami. mahasiswi dalam membuat kerutan terkesan kaku dan terlihat kurang pembauran yang tepat. Padahal untuk mempertegas warna kerutan pada rias wajah karakter perempuan tua harus dibantu dengan pensil alis atau kosmetik body painting yang bewarna coklat dan hitam.

Dampak dari kurang pemahaman mahasiswi dalam menguasai teknik yang tepat dalam pembuatan karakter perempuan tua membuat hasil riasan terkesan kurang alami.

Berdasarkan uraian di atas, diharapkan terdapat alternatif kosmetik yang dapat digunakan untuk merias wajah karakter perempuan tua dengan hasil yang lebih baik dilihat dari kehalusan riasan, ketajaman warna, dan ketepatan garis kerutan. maka penulis tertarik untuk melakukan penelitian dengan judul "Perbedaan Hasil Rias Wajah 
Karakter Tua dengan Menggunakan Kosmetik Body Painting dan Pensil alis".

\section{METODE}

Metode penelitian ini menggunakan metode eksperimen semu (quasi exsperiment). Penelitian dilakukan dalam desain Non equivalent control group design. Sampel pada penelitian ini dibagi menjadi dua kelompok, yaitu kelompok kelompok eksperimen 1 dengan simbol (X1), kelompok eksperimen 2 dengan simbol (X2). Teknik pengambilan sampel dilakukan dengan teknik purposive sampling yaitu teknik pemilihan sekelompok subjek didasarkan atas ciri-ciri tertentu yang erat dengan ciri-ciri populasi yang sudah diketahui sebelumnya. Sampel dalam penelitian ini adalah sebagian dari sekelompok orang yang memiliki kulit wajah normal dengan jumlah sampel 6 orang merupakan wanita berumur 18-23 tahun. Sampel yang diambil harus homogen, Tempat dan waktu penelitian dilakukan di Workshop Program Studi Pendidikan Tata Rias dan Kecantikan, Fakultas Pariwisata dan Perhotelan, Universitas Negeri Padang. Teknik analisis data dilakukan dengan menggunakan menggunakan. Uji analisis $t$ independen.

\section{HASIL DAN PEMBAHASAN}

\section{A. Hasil Penelitian}

1. Deskripsi Hasil Penelitian Rias Wajah Karakter Tua dengan menggunakan Kosmetik Body Painting (X1).

Tabel 1. Skor Tingkat Keberhasilan dalam rias wajah karakter tua menggunakan kosmetik body painting (X1)

\begin{tabular}{|c|c|c|c|}
\hline Sampel & Kehalusan & Ketajaman & Ketepatan \\
\hline 1 & 15 & 19 & 20 \\
\hline 2 & 18 & 14 & 13 \\
\hline 3 & 18 & 20 & 20 \\
\hline Jumlah & 51 & 53 & 53 \\
\hline $\begin{array}{c}\text { Rata- } \\
\text { rata }\end{array}$ & $\mathbf{3 . 4}$ & $\mathbf{3 . 5}$ & $\mathbf{3 . 5}$ \\
\hline
\end{tabular}

Berdasarkan Tabel 1 di atas dapat diuraikan bahwa penilaian pada rias wajah karakter tua menggunakan kosmetik body painting secara rata-rata menunjukkan skor 3,4 pada kehalusan, ketajaman skor 3,5 dan pada ketepatan menunjukkan rata-rata 3,5 dengan kategori "sangat baik"

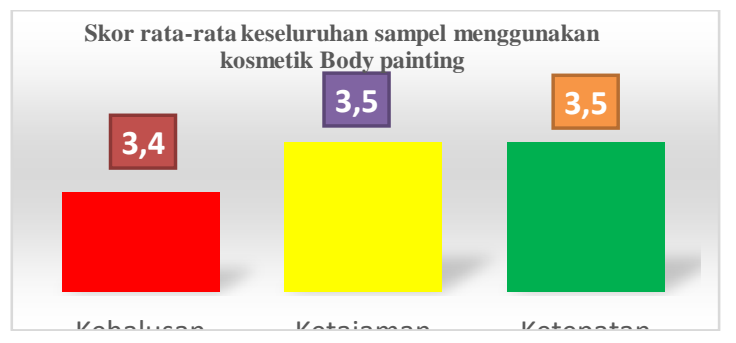

2. Deskripsi Hasil Penelitian Rias Wajah Karakter Tua dengan menggunakan Pensil Alis (X2)

Tabel 2. Skor Tingkat Keberhasilan dalam rias wajah karakter tua menggunakan pensil alis (X2)

Berdasarkan tabel 21 di atas dapat diuraikan bahwa penilaian pada rias wajah karakter tua menggunakan pensil alis secara rata-rata menunjukkan skor 2,2 pada kehalusan, ketajaman skor 2,3 dan pada ketepatan menunjukkan rata-rata 2,2 dengan

\begin{tabular}{|c|c|c|c|}
\hline Sampel & Kehalusan & Ketajaman & Ketepatan \\
\hline 1 & 12 & 12 & 10 \\
\hline 2 & 11 & 10 & 13 \\
\hline 3 & 20 & 13 & 10 \\
\hline Jumlah & 33 & 35 & 33 \\
\hline $\begin{array}{c}\text { Rata- } \\
\text { rata }\end{array}$ & $\mathbf{2 . 2}$ & $\mathbf{2 . 3}$ & $\mathbf{2 . 2}$ \\
\hline
\end{tabular}

kategori "kurang baik"

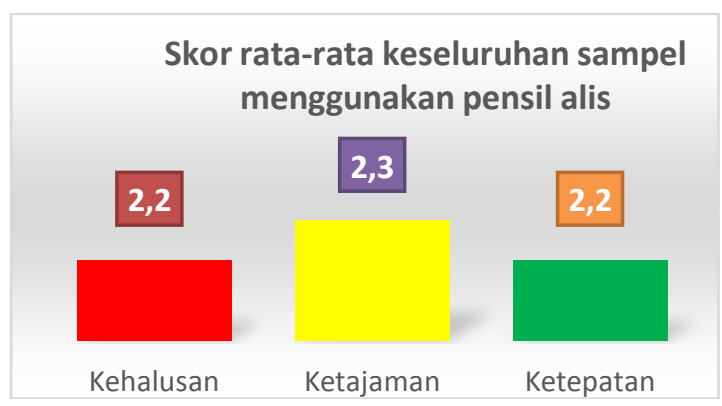

B. Uji Persyaratan Analisis

1. Uji Normalitas

Tabel 4 Uji Normalitas Pada Ketiga Kelompok 
One-Sample Kolmogrov- Smirnov Test

\begin{tabular}{|c|c|c|c|c|}
\hline & & $\begin{array}{c}\text { Kehalus } \\
\text { an }\end{array}$ & $\begin{array}{l}\text { Ketajam } \\
\text { an }\end{array}$ & $\begin{array}{c}\text { Ketepata } \\
\mathrm{n} \text { garis } \\
\text { kerutan }\end{array}$ \\
\hline \multicolumn{2}{|l|}{$\mathrm{N}$} & 6 & 6 & 6 \\
\hline \multirow{3}{*}{$\begin{array}{c}\text { Normal } \\
\text { Parameters }^{\mathrm{a}}\end{array}$} & Mean & 2.8333 & 2.9000 & 3.0000 \\
\hline & & & & \\
\hline & $\begin{array}{c}\text { Deviatio } \\
n\end{array}$ & 0.66232 & 0.81731 & 0.92952 \\
\hline \multirow{3}{*}{$\begin{array}{l}\text { Most Extreme } \\
\text { Differences }\end{array}$} & Absolute & 0.244 & 0.230 & 0.192 \\
\hline & Positive & 0.244 & 0.230 & 0.192 \\
\hline & Negative & -0.210 & -0.198 & -0.192 \\
\hline \multirow{2}{*}{\multicolumn{2}{|c|}{$\begin{array}{l}\text { Kolmogorov-Smirnov Z } \\
\text { Asymp. Sig. (2-tailed) }\end{array}$}} & 0.244 & 0.230 & 0.192 \\
\hline & & 0.200 & 0.200 & 0.200 \\
\hline \multicolumn{2}{|c|}{$\begin{array}{l}\text { a. Test distribution is } \\
\text { Normal. }\end{array}$} & & & \\
\hline
\end{tabular}

Berdasarkan uraian di atas didapatkan semua uji mempunyai nilai $\mathrm{p}>0,05$, hal ini menunjukkan data berdistribusi normal.

\section{Uji Homogenitas}

\section{Tabel 5 Uji Homogenitas Pada Ketiga Kelompok}

\section{Test of Homogeneity of Variances}

\begin{tabular}{|l|r|r|r|r|}
\hline & $\begin{array}{c}\text { Levene } \\
\text { Statistic }\end{array}$ & df1 & df2 & Sig. \\
\hline Kehalusan & 6.400 & 1 & 4 & 0.065 \\
Ketajaman & 4.780 & 1 & 4 & 0.094 \\
Ketepatan & 0.000 & 1 & 4 & 1.000 \\
\hline
\end{tabular}

Berdasarkan uraian di atas didapatkan semua uji mempunyai nilai $\mathrm{p}>0,05$, hal ini menunjukkan data homogen.

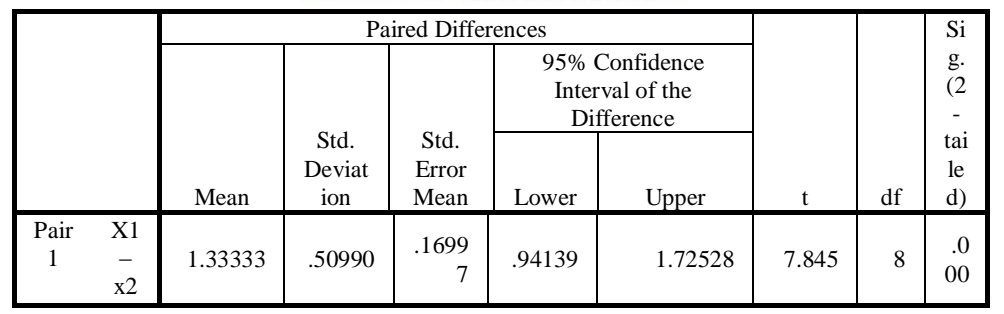

Berdasarkan tabel diatas dapat diperhatikan bahwa nilai t hitung adalah (7.845) sedangkan nilai t tabel untuk ketentuan df 8 pada taraf signifikan 5\% adalah sebesar (1.860). Dengan demikian harga t hitung > t tabel (5.810>1.860), maka Ho ditolak, artinya terdapat perbedaan pengaruh yang signifikan terhadap penggunaan kosmetik body painting dengan pensil alis pada rias wajah karakter perempuan tua

\section{B. Pembahasan}

\section{Rias Wajah Karakter Perempuan Tua Menggunakan Kosmetik Body Painting (X1)}

Berdasarkan hasil analisis yang telah dilakukan, maka rias wajah karakter perempuan tua pada kelompok eksperimen 1 menggunakan kosmetik body painting (X1) yang dinilai dari kehalusan riasan, ketajaman warna dan ketepatan garis kerutan menunjukan hasil riasan yang signifikan, yang dapat dilihat dari data penelitian hasil penelitian menunjukkan bahwa rata-rata dari eksperimen 1 menggunakan kosmetik body painting (X1) 3.778 dengan kategori sangat baik.

Menurut Thowok (2012:30) pembuatan garis kerut untuk mengambarkan kulit keriput pada dahi, hidung bagian atas, seputar mata, garis tertawa dan bibir disesuaikan dengan usia karakter.

Penggunaan kosmetik body painting sebagai kosmetik penunjang dalam pembuatan kerutan pada rias wajah karakter perempuan tua dianggap efisien karena dapat membantu hasil riasan lebih halus, tajam dan tepat pada kerutannya.

Menurut penelitian yang dilakukan oleh Aprilya (2014:110) mengungkapkan bahwa aspek kehalusan riasan pada karakter perempuan tua dengan menggunakan kosmetik body painting lebih halus dibandingkan dengan menggunakan foundation. Dari aspek ketajaman warna, hasil tata rias wajah karakter tua menggunakan kosmetik body painting lebih tajam dari pada foundation dilihat dari garis kerutan dan efek cekung yang diciptakan. Sementara dari aspek ketepatan garis kerutan, 
kosmetik body painting lebih tepat dibandingkan foundation. Secara keseluruhan, tata rias wajah karakter perempuan tua dengan menggunakan kosmetik body painting lebih baik dari pada yang menggunakan foundation.

Dengan penjelasan di atas dapat disimpulkan bahwa kosmetik body painting dapat digunakan untuk menunjang dalam pembuatan kerutan pada rias wajah karakter perempuan tua.

\section{Rias Wajah Karakter Perempuan Tua Menggunakan Kosmetik Pensil Alis (X2)}

Berdasarkan hasil analisis yang telah dilakukan, maka rias wajah karakter perempuan tua pada kelompok eksperimen 2 menggunakan pensil alis (X2) yang dinilai dari kehalusan riasan, ketajaman warna dan ketepatan garis kerutan menunjukan hasil riasan yang kurang signifikan, yang dapat dilihat dari data penelitian hasil penelitian menunjukkan bahwa rata-rata dari eksperimen 2 menggunakan pensil alis (X2) 2.2444 dengan kategori kurang baik.

Penggunaan pensil alis sebagai kosmetik penunjang dalam pembuatan kerutan pada rias wajah karakter perempuan tua dianggap kurang efisien karena hasil riasan yang didapat dari segi kehalusan riasan, ketajam warna dan ketepatan kerutan terlihat kurang alami dan kaku .

Thowok (2012:30) menjelaskan pembuatan garis kerutan garis kerutan wajah dapat dibuat menggunakan pensil alis warna hitam dan cokelat dengan goresan cenderung tebal dan kaku.

\section{Perbedaan Hasil Rias Wajah Karakter Perempuan Tua Menggunakan Kosmetik Body painting dan Pensil Alis}

Terlihat pada penelitian bahwa adanya perbedaan dari segi indikator tingkat kehalusan riasan, ketajaman warna dan ketepatan kerutan menggunakan rias wajah karakter perempuan tua pada kedua kelompok, dimana nilai terbaik didapatkan pada kelompok menggunakan kosmetik body painting dibandingkan dengan menggunakan pensil alis.

Berdasarkan hal ini maka menurut analisa peneliti terhadap penelitian ini adalah ditemukan bahwa adanya pengaruh signifikan terhadap penggunaan kosmetik body painting dan pensil alis pada rias wajah karakter perempuan tua, dimana penggunaan kosmetik body painting memberikan hasil yang lebih baik dari segi kehalusan hasil riasan, ketajaman riasan dan ketepatan kerutan. Hal ini dapat disebabkan karena kosmetik body painting berbentuk krim memiliki tekstur yang lunak dan mudah di aplikasikan, sehingga pada saat pengaplikasian pembuatan kerutan sangat mudah dan tidak mengalami kesulitan dalam membaurkannya, sehingga hasil yang didapat lebih terkesan alami pada riasan. Dan rias karakter perempuan tua diperlukan pemilihan kosmetika yang tepat, agar dapat menunjang dari karakter perempuan tua itu sendiri.

Berdasarkan dari penelitian yang telah dilakukan penulis menyarankan untuk dapat melakukan rias wajah karakter perempuan tua menggunakan kosmetik body painting karena hasil riasan yang didapatkan lebih terkesan alami.

\section{Kesimpulan dan Saran}

\section{A. Kesimpulan}

Berdasarkan hasil penelitian tentang perbedaan hasil rias wajah karakter perempuan tua dengan menggunakan kosmetik body painting dan pensil alis maka dapat disimpulkan bahwa :

1. Dari analisis hasil rias wajah karakter perempuan tua menggunakan kosmetik body painting terdapat hasil yang signifikan dan efisien pada penggunaan pada rias wajah karakter perempuan tua dengan skor rata- rata 3.5778 dengan kategori sangat baik.

2. Dan dari analisis hasil rias wajah karakter perempuan tua menggunakan pensil alis terdapat hasil yang kurang efisien dengan skor rata-rata 2.2444 dengan kategori kurang baik.

3. Sedangkan perbedaan hasil yang signifikan antara penggunaan dari kosmetik body painting dan pensil alis dapat dijelaskan melalui harga $\mathrm{t}$ hitung > t tabel $(7.845>1.860)$ hal ini membuktikan bahwa adanya perbedaan yang signifikan yang didapat dari penggunaan kosmetik body painting dan pensil alis.

B. Saran

Setelah melakukan penelitian ini penelitian dapat memberikan saran bagi pihak terkait dalam bidang tata rias dan kecantikan, yaitu:

1. Kepada Jurusan Tata Rias dan Kecantikan

Kepada Prodi Pendidikan Tata

Rias dan Kecantikan Fakultas Pariwisata dan Perhotelan. hasil penelitian ini dapat menambah dan 
masukan konsep dan teori untuk kuliah Foto/tv dan Film yang selanjutya berguna sebagai dasar dalam mengembangkan keilmuan di bidang kecantikan.

2. Kepada Mahasiswa

Bagi mahasiswa Program studi D4 Pendidikan Tata Rias dan Kecantikan hasil penelitian ini dapat memberikan ilmu dan pengetahuan rias wajah karakter perempuan tua.

3. Kepada Responden

Bagi responden hasil penelitian ini dapat bermanfaat untuk merias wajah karakter perempuan tua dan menambah pengetahuan kosmetik yang bisa digunakan pada saat rias wajah karakter perempuan tua.

4. Kepada Peneliti

Bagi peneliti, selain syarat menyelesaikan pendidikan juga merupakan kesempatan untuk mencoba dan berlatih langsung melakukan ekperimen dalam melakukan ilmu-ilmu yang diperoleh dari perkuliahan.

5. Kepada Masyarakat Umum

Bagi masyarakat umum, sebagai bahan bahan bacaan informasi tentang penggunaan kosmetik body painting dan pensil alis pada rias wajah karakter perempuan tua.

\section{DAFTAR PUSTAKA}

Andiyanto. 2003. The Make Over, RahasiaRiasWajahSempurna. Jakarta PT. Graamedia Pustaka Utama.

Arikunto, Suharsimi. 2013. Dasar-dasar Evaluasi Pendidikan.Jakarta: Bumi Aksara.

Aprilya, Putri. 2014. Perbedaan Hasil Jadi Tata Rias Wajah Karakter Perempuan Tua dengan Menggunakan Kosmetik Body Painting dan Foundation. E-Journal. Volume 03 Nomer 01 Tahun 2014, Edisi Yudisium

Arikunto, Suhasimi. 2010. Prosedur Penelitian Suatu Pendekatan Praktik. Jakarta: Rineka Cipta.

Bungin, Burhan. 2009. Analisis Penelitian Data Kualitatif. Jakarta: Raja Grafindo

Direktorat Pembinaan Kursus dan Pelatihan. 2016. Bahan Ajar Kursus Dan Pelatihan Tata

\section{Kecantikan Kulit; Merias Wajah Foto/Film Karakter dan Fantasi. Jakarta: Kementerian Pendidikan dan Kebudayaan}

Departeman Pendidikan Nasional. 2001. Merias Wajah Karakter Orang Tua. Jakarta: Direktorat Pendidikan Menengah Kejuruan

Ghozali, Imam. 2007. Aplikasi analisis multivariate dengan program SPSS. BPUniversitas Diponegoro, Semarang

Ilahi Nikmah, 2010. Kecantikan Wajah Terkini. Jogjakarta; Flash Books

Iswoyo ,Edi Bayu.2015. Penciptaan Seni Lukis Ilusi Tiga Dimensi. Jurnal Pendidikan Seni Rupa.

Kusantati, Herni dkk. 2008. Tata Kecantikan Kulit Jilid 2. Jakarta. Departement Pendidikan Nasional.

Kusantati, Herni. 2008. Tata Kecantikan Kulit Jilid 3. Direktorat Pembinaan Sekolah Menengah Kejuruan. Jakarta.

Lutfi, M.S. 2007. Kiat Memahami Melakukan Penelitian. Padang: UNP Press

Muliyawan, Dewi dan Suriana, Neti. 2013. A-Z tentang Kosmetik. Jakarta: Elex Media. Komputindo

Paningkiran, Halim. 2013. Make up Karakter untuk Televisi dan Film. Jakarta: Gramedia Pustaka Utama

Punaji, Setyosari. 2010. Metode Penelitian Penelitian dan Pengembangan. Jakarta: Kencana.

Pancawardani. 2013. Pengaruh Penggunaan Jenis Kosmetik Terhadap Hasil Paes Tata Rias Pengantin Yogya Putri. Jurnal Tata Rias Vol 2, No 1.

Ridwan. 2009. Prosedur Pelaksanaan Penelitian. Bandung. Alfa Beta

Ridwan. 2009. Metode dan Teknik Menyusun Proposal Penelitian. Bandung: Alfa Beta

Rediasa dan Sutrisno.2015.pertunjukan body painting dibali sebagai objek 
pariwisata.jurnal kajian seni vol 02. No 01 .

Bali: Universitas pendidikan ganesha

Susiwi, S. 2009. Penelitian Organoleptik. FMIPA Universitas Pendidikan Indonesia

Sugiyono. 2010. Metode Penelitian Pendidikan Pendekatan Kuantitatif, Kualitatif, dan $R \& D$. Bandung: Alfabeta

Santoso, Eko, dkk. 2008. Seni Teater Jilid 2 Untuk Sekolah Menengah Kejuruan. Jakarta : Direktorat pembinaan sekolah menengah kejuruan .

Santoso, Singgih. 2010. Statistik Non Parametrik Konsep dan Aplikasi dengan SPSS. Jakarta: Elex Media Komputindo.

Sudjana. 1991. Desain dan Analisis Eksperimen. Bandung: Tarsito

Sugiyono. 2008. Metode Penelitian Kuantitatif Kualitatif dan $R \quad \& D$. Bandung: Alfabeta.

Sudjono, Anas. 2003. Pengantar Statistik Pendidikan. Jakarta : Raja Grafindo

Thowok, Didik Nini. 2012. Stage Make up. Jakarta: Gramedia Pustaka Utama

Tilaar, Martha. 2009. Maximize Your Beaut Jakarta Pusat: PT Puspita Martha. Jakarta GramediaPustakaUtama. 